\title{
Distribution of Polycyclic Aromatic Hydrocarbons (PAHs) in Soil Samples from Regions Around Loda-Irele Bitumen Field, Nigeria
}

\author{
Adams Udoji Itodo*, Rufus Sha'Ato and Michael Imisi Arowojolu \\ Department of Chemistry, University of Agriculture, P. M. B. 2373 Makurdi, Benue State, Nigeria. \\ *Corresponding Author Email: itodoson2002@gmail.com \\ Received 13 June 2017, Revised 20 March 2018, Accepted 30 March 2018
}

\begin{abstract}
Polycyclic aromatic hydrocarbons (PAHs) were investigated in soils of Loda-Irele (geographical coordinate $6^{\circ} 29^{\prime} 0^{\prime \prime} \mathrm{N} 4^{\circ} 52^{\prime} 0^{\prime \prime} \mathrm{E}$ ), Nigeria. Soxhlet extraction technique was used for soil PAH extraction using dichloromethane as extracting solvent. PAHs in the samples are estimated using Gas chromatography-mass spectrometer (GC-MS). The PAH concentrations were higher than 1$10 \mathrm{ppb}$ in most samples, pointing to anthropogenic and petrogenic sources of the pollutants. Most PAH concentrations fall within the expected limits for a rural environment and below the threshold limit. However, 12.08 and14.68 ppb for Benzo(e)pyrene and $5.62 \mathrm{ppb}$ for Indenol (1, 2, $3-c d)$ pyrene exceeded the expected limit. Dominating $4-6$ ring PAHs showed the PAHs were from pyrolytic sources. The concentrations of PAHs are not significant $(p>0.05)$ compared to maximum allowable concentrations in soils.
\end{abstract}

Keywords: Environment, Pollution, Bituminous, PAHs, GC-MS, Petrogenic.

\section{Introduction}

Environmental pollution by unsustainable anthropogenic, results in public health challenges [1]. Persistent organic pollutants (POPs) are chemicals species that persist in the environment, undergo bioaccumulation via food web, and pose a risk of causing adverse effects to man and the environment. POPs move over long distances in near atmosphere, resulting in vast distribution across the earth including unsuspecting zones. In nature, they alter plant, animal growth and yield. Others include reduced reproduction, gene mutation, behavioural changes and death. They are cancerous and interrupt the immune and endocrine. Some of these pollutants include adrin, polychlorinated biphenyls (PBCs), chlordane, dieldrin, polychlorinated dibenzofurans, toxaphene [2].

In May 2001, a global agreement on regulating POPs incorporates tools for cutting out
12 POPs on a worldwide scale. Among these twelve POPs, is benzo(e)pyrene $(\mathrm{B}(\mathrm{a}) \mathrm{P})$ is a priority and the most toxic [3].

Polynuclear aromatic hydrocarbons (PAHs) contain carbon and hydrogen with a bonded ring, holding at least two benzene rings [4]. These stable pollutants composed of only carbon and hydrogen. Largely, they occur as complex and not single substances. They naturally exist as compounds and can be synthesized as separate compounds for use in research. In its pure state chemicals, PAHs are colourless, white or pale yellow-green solids with faint and pleasant odour [5]. PAHs due to metabolism in human are not classified as POPs and less bio-accumulate [6]. Several PAHs are powerful carcinogens in existence, causing tumours in some organisms exposed to it even at microgram quantities. PAHs are inducer of cancer and precancerous 
lesions are devastating as the main contributor to the recent growth in cancer rates documented for industrialized countries. PAHs are mutagenic and teratogenic in nature or in the transformed from $[5,7]$. They are broadly and readily spread in the environment and are in organisms [8].

Bitumen is a sticky, black and viscid or semisolid hydrocarbons (HCs) which are described as the heaviest and thickest form of petroleum [9].

In agricultural soils, vast numbers of PAHs strongly adhered to the organic matter. PAH degradation is unattainable and having the potential of persisting in the soil for many centuries. The persistence poses prolong threat to the environment. An exception to prolong persistence is low molecular weight PAHs vanishing via degradation, volatilization and leaching [10]. Polynuclear aromatic hydrocarbons have a unique characteristic of being carcinogenic, mutagenic and teratogenicity that threaten human health. Bitumen have very small quantities of $4-6$ condensed rings PAHs [11].

This research is aimed at analyzing PAHs in Irele bitumen deposit field, Nigeria. The study focuses on qualitative and quantitative GC-MS characterization of agricultural soil for some toxic PAHs listed among priority pollutants by US EPA.

\section{Materials and Methods Materials}

A global positioning system (GPS), FTIR, UV Spectrophotometer, GC-MS and routine laboratory apparatus were employed for this research.

\section{Sampling sites description}

Irele $\left(6^{\circ} 29^{\prime} 0^{\prime \prime} \mathrm{N} \quad 4^{\circ} 52^{\prime} 0^{\prime \prime} \mathrm{E}\right)$ is a Local Government Area in Ondo State, Nigeria. The town covers an area of 963 square kilometers. The population of Irele is 145,166 . Temperature is moderate throughout the year. Minimum and maximum Temperature is around $24{ }^{\circ} \mathrm{C}$ and $33{ }^{\circ} \mathrm{C}$, respectively. Bitumen seepage points in the bituminous area especially land used for agricultural purposes, reserve forest and rivers.
This study focuses on seepage location where bitumen exploration has flagged off.

\section{Soil Sampling}

The sampling of soil was done as earlier described and documented [11,12]. Sampling as coded in Table 1 was carried out during the dry season. Soil samples were from five points in Loda-Irele at depths of 1- $5 \mathrm{~cm}$. Composite sample (SLSP) is from around the seepage. Four samples from $100 \mathrm{~m}$ to the north (SLN), south (SLS), east (SLE) and west (SLW) from the seepage. The sampling points positioned using GPS is to ensure uniformity. Collected samples were in aluminium foil to prevent contamination. Samples were taken to the laboratory and kept at $-20{ }^{\circ} \mathrm{C}$. Samples were oven dried at $150{ }^{\circ} \mathrm{C}$ to $200{ }^{\circ} \mathrm{C}$ for about $30 \mathrm{mins}$, homogenized and sieved through a mesh of $2 \mathrm{~mm}$ to remove stones and other debris and stored at -20 ${ }^{\circ} \mathrm{C}[13]$.

Table 1. Sample Code, Geographical Coordinates and Description.

\begin{tabular}{|c|c|c|c|c|}
\hline $\mathbf{S} / \mathbf{N}$ & Samples & $\begin{array}{l}\text { Sample } \\
\text { Codes }\end{array}$ & $\begin{array}{l}\text { Geographical } \\
\text { Coordinates }\end{array}$ & Description \\
\hline 1 & Soil & SLSP & $\begin{array}{l}6.652008, \\
4.889359\end{array}$ & $\begin{array}{l}\text { Soil sample from } \\
\text { the bitumen } \\
\text { seepage vicinity }\end{array}$ \\
\hline 2 & Soil & SLN & $\begin{array}{l}6.652893, \\
4.889305\end{array}$ & $\begin{array}{l}\text { Soil sample from } \\
100 \mathrm{~m} \text { North of } \\
\text { the bitumen } \\
\text { seepage }\end{array}$ \\
\hline 3 & Soil & SLS & $\begin{array}{l}6.651096, \\
4.889385\end{array}$ & $\begin{array}{l}\text { Soil sample from } \\
100 \mathrm{~m} \text { South of } \\
\text { the bitumen } \\
\text { seepage }\end{array}$ \\
\hline 4 & Soil & SLE & $\begin{array}{l}6.652041, \\
4.890271\end{array}$ & $\begin{array}{l}\text { Soil sample from } \\
100 \mathrm{~m} \text { East of the } \\
\text { bitumen seepage }\end{array}$ \\
\hline 5 & Soil & SLW & $\begin{array}{l}6.651982, \\
4.888456\end{array}$ & $\begin{array}{l}\text { Soil sample from } \\
100 \mathrm{~m} \text { West of } \\
\text { the bitumen } \\
\text { seepage }\end{array}$ \\
\hline 6 & Soil & SLC & $\begin{array}{l}6.369382, \\
4.940338\end{array}$ & $\begin{array}{l}\text { Soil sample from } \\
\text { none bituminous } \\
\text { region as Control }\end{array}$ \\
\hline
\end{tabular}

Commercial PAHs standard containing 8 out of 16 US EPA priority PAHs was supplied by Sigma Aldrich, USA and delivered by Bristol Scientific, Lagos. PAH standards contain 500 ppm fluorene, phenanthrene, pyrene, benz[a]anthracene, 
benzo[b]fluoranthene, benzo[a]pyrsne, benzo [g,h,i]perylene and indeno[1,2,3-cd]pyrene. Each standard solution was run on the GC-MS to calibrate the instrument prior to GC-MS quantification. The GC-MS chromatogram of the standard is shown in (Fig. 1). All reagents used in the analysis were of analytical grade (AR).

Figure 1. Chromatogram of the PAHs standard procedure for soil extraction

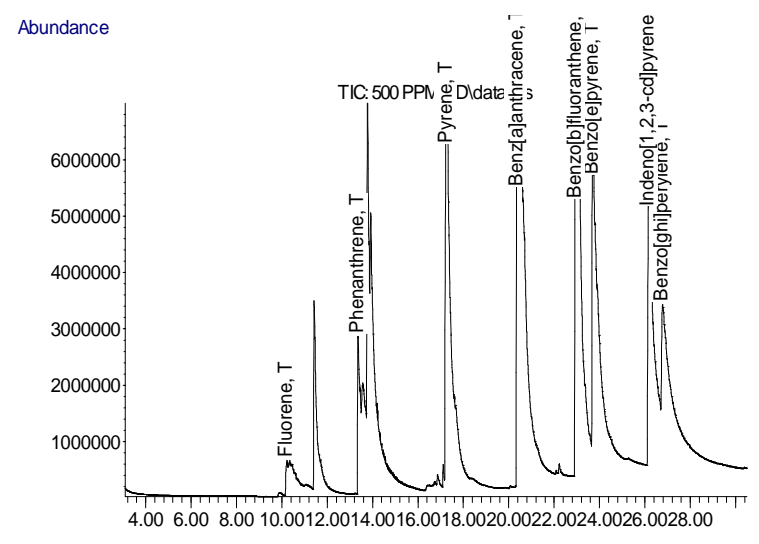

Time-->

The pretreated soil samples were extracted with dichloromethane using a Soxhlet extractor [14], concentrated and cleaned up using silica gel column chromatography $[13,15]$. The soil sample $(10 \mathrm{~g})$, weighed into the extraction thimble followed by addition of $60 \mathrm{~mL}$ dichloromethane. The extraction continued for 2 hours. The extract, concentrated to dryness using a rotary evaporator, transferred to amber vials and kept in the refrigerator for cleanup $[11,16]$.

Clean up: The soil extract was purified using silica gel packed column chromatography and eluted with dichloromethane. The first $1.0 \mathrm{~mL}$ of eluate, discarded and $5.0 \mathrm{~mL}$ of eluate sent into the amber vial and kept in the refrigerator for analyses $[16,17]$.

\section{GC-MS conditioning}

An Agilent Technology GC-MS comprises of a 7890 gas chromatography and 5975C mass spectrometer detector was used. The instrument comprises a column of thickness $0.25 \mu \mathrm{m}$ and helium as carrier gas at the rate of $1 \mathrm{~mL} / \mathrm{min}$. Temperature program of initial temperature at $60{ }^{\circ} \mathrm{C}$ hold for $0.5 \mathrm{~min}$ then ramp to $240{ }^{\circ} \mathrm{C}$ at the rate of $10{ }^{\circ} \mathrm{C} / \mathrm{min}$ to the final temperature at $300{ }^{\circ} \mathrm{C}$ hold for $6 \mathrm{~min}$. The extracts were analyzed using the (GC-MS) for both qualitative and quantitative analyses [18].

\section{Method validation}

Relative percent difference (\% RPD): An early solvent blank was tested prior PAH analysis. Test, repeated in double after every sample. The Relative Percent Difference (\% RPD) was estimated as [11,13]:

$$
\% \mathrm{RPD}=\left(\frac{2\left(\mathrm{D}_{1}-\mathrm{D}_{2}\right)}{\mathrm{D}_{1}+\mathrm{D}_{2}}\right) \times 100
$$

Where $D_{1}$ is analyte concentration in the first duplicate sample and $\mathrm{D}_{2}$ is the concentration of the analyte in the second duplicate sample [11].

Limit of detection (LOD) and limit of quantification (LOQ): Calculation of LOD and LOQ using concentration of the blank sample run is.

$$
\begin{aligned}
& \mathrm{LOD}=\frac{3 s_{b}}{\mathrm{a}} \\
& \mathrm{LOQ}=\frac{\operatorname{los}_{\mathrm{b}}}{\mathrm{a}}
\end{aligned}
$$

Where $s_{b}$ stands for the standard deviation of the blanks and $\mathrm{a}$ is the slope of the calibration curve [19].

\section{Results and Discussion Physicochemical parameters of soil samples}

Bulk density: Bulk density measures the degree of compaction of the soil material. The bulk density of the soil samples are given in Table 2. Values agreed with reported data [20]. From the results, organic carbon of the soil samples increases as the bulk density decreases. An increase in organic matter (or organic carbon) is needed for the proper growth of the plants [21]. Integrating organic matter in a compacted soil lowers the bulk density and upturns electrical charge. Thus, increasing repulsive forces between soil particles and improves soil total strength [22]. 
Moisture content: The moisture content of the soil is a mark of water present in the soil. Moisture contents of the soil of Loda-Irene as presented in (Table 2) agreed with the values reported [16]. The moisture content of the soil samples ranges from $10.88 \%$ in SLE to $15.06 \%$ in SLS. Comparing moisture content and the mean concentration of PAHs in the soil samples, concentration of PAHs increases as the moisture content decreases. Consumption and carbon dioxide production in normal agricultural soils depends on soil moisture content and temperature [23].

Electrical conductivity: Electrical conductivity is an indirect signal of the strength of the nutrient solution. Electrical conductivity for the soil samples ranges from 8.76 to $14.29 \mu \mathrm{Scm}^{-1}$ while that of the water sample ranged from 9.01 to 14.0 $\mu \mathrm{Scm}^{-1}$. The electrical conductivity increases as the PAHs concentration decreases in SLE through SLSP to SLN for soil samples and RS to RD in water samples. The electrical conductivity level for hydroponic is between 1500 to $2500 \mu \mathrm{Scm}^{-1}$ and higher electrical conductivity deters nutrient uptake due to increase in osmotic pressure while lower may affect plant health, growth and yield [24]. The conductivity of the water for the whole study area stands at an average of 11.54 $\mu \mathrm{Scm}^{-1}$. This could be a signal of little solute dissolution in the river, rapid ion-exchange between the soil and water, or a poor and rather insoluble geologic rock and mineral types [25].

pH: The $\mathrm{pH}$ found in the soil samples ranges from $\mathrm{pH} 7.20$ to $\mathrm{pH} 8.83$, suggesting the soil ranges from $\mathrm{pH}$ neutral to strongly alkaline according to USDA[26] (2011). This range of soil $\mathrm{pH}$ values suits the availability of most essential macro nutrients. Some nutrients become retained in the soil at particular $\mathrm{pH}$ levels. Certain elements $(\mathrm{P}, \mathrm{K}$, $\mathrm{S}, \mathrm{Ca}, \mathrm{Mg}, \mathrm{N}$ ) are expected to be present in the region. The soil of high alkalinity may lead to deficiencies in some elements $(\mathrm{Fe}, \mathrm{Mn}, \mathrm{Cu}, \mathrm{B}$ and $\mathrm{Zn})$.

Soil particle size: Particle size has a link with soil stability, morphology, genesis, classification and mapping; it is used as a basis of soil textural classification. It influences many physical and biogeochemical properties of soils such as soil water holding capacity (drainage), ventilation and proneness or vulnerability to erosion and thus, it is a vital aid in soil management.

Table 2. Physicochemical Parameters of Soil Samples from Irele Bitumen Field.

\begin{tabular}{lccccc}
\hline Parameter & SLSP & SLN & SLS & SLE & SLC \\
\hline $\mathrm{pH}$ & 8.79 & 7.62 & 8.75 & 8.83 & 7.66 \\
& \pm & \pm & \pm & \pm & \pm \\
& 0.07 & 0.02 & 0.07 & 0.04 & 0.03 \\
Temperature $\left({ }^{\circ} \mathrm{C}\right)$ & 28.13 & 28.16 & 28.16 & 28.15 & 28.60 \\
& \pm & \pm & \pm & \pm & \pm \\
& 0.06 & 0.24 & 0.24 & 0.08 & 0.53 \\
Electrical Conductivity & 9.21 & 13.45 & 12.00 & 8.76 & 10.87 \\
$\left(\mu S c{ }^{-1}\right)$ & \pm & \pm & \pm & \pm & \pm \\
& 0.47 & 0.86 & 0.04 & 0.37 & 0.21 \\
Moisture Content $(\%)$ & 11.20 & 13.09 & 15.06 & 10.88 & 16.03 \\
& \pm & \pm & \pm & \pm & \pm \\
& 0.13 & 0.28 & 0.13 & 0.32 & 0.03 \\
Bulk Density $\left(\mathrm{g} / \mathrm{cm}^{3}\right)$ & 1.18 & 1.19 & 1.20 & 1.26 & 1.07 \\
& \pm & \pm & \pm & \pm & \pm \\
& 0.01 & 0.01 & 0.02 & 0.02 & 0.06 \\
& & & & & \\
Total Organic Carbon & 2.18 & 2.05 & 2.11 & 1.94 & 2.11 \\
$(\%)$ & \pm & \pm & \pm & \pm & \pm \\
& 0.02 & 0.09 & 0.03 & 0.05 & 0.05 \\
& & & & &
\end{tabular}

The textural arrangement of the soil samples revealed that the soil falls into various textural classes. This study reveals clay-loam soil type. The clay quota of the soil is usually with a high density due to the presence of decayed plant remains, the remains of insects and animals. Soil with a high fine particle (silt and clay) is known for lesser pore diameters and a higher penetration resistance than a soil with a huge amount of coarse particles [27].

FTIR Characterization: FTIR spectra of the soil sample from bitumen field (SLSP) and nonbituminous field (SLC) were interpreted in (Table 3). Various functional groups such as $\mathrm{C}-\mathrm{H}$, $\mathrm{C}=\mathrm{C}-\mathrm{C}, \mathrm{C}-\mathrm{O}$ and $\mathrm{C}=\mathrm{O}$, were found to be available in the soil samples. The FTIR spectra of organic compounds within a range of $2960-650 \mathrm{~cm}^{-1}$ were recorded and presented in Table 3 to confirm the presence of all or some of the groups which suggested the presence of one or more aromatic rings [28]. 
Table 3. FTIR spectra characteristics of the Soil samples.

\begin{tabular}{|c|c|c|c|c|}
\hline \multirow[t]{2}{*}{$\begin{array}{l}\text { Functional } \\
\text { group }\end{array}$} & \multirow{2}{*}{$\begin{array}{l}\text { Group } \\
\text { Freq. } \\
\left(\mathrm{cm}^{-1}\right)\end{array}$} & \multicolumn{2}{|c|}{$\begin{array}{c}\text { Observed } \\
\text { Frequency }\left(\mathrm{cm}^{-1}\right)\end{array}$} & \multirow[t]{2}{*}{$\begin{array}{l}\text { Molecular } \\
\text { Assignment }\end{array}$} \\
\hline & & SLSP & $S L C$ & \\
\hline \multirow[t]{2}{*}{$\mathrm{C}-\mathrm{H}$} & $\begin{array}{c}900- \\
670 \\
\\
770- \\
735\end{array}$ & $\begin{array}{l}673.17 \\
792.80\end{array}$ & $\begin{array}{l}701.21 \\
804.37 \\
736.54\end{array}$ & $\begin{array}{l}\text { Aromatic C-H out-of- } \\
\text { plane bend, } \\
\text { monosubstitution, } \\
\text { disubstitution } \\
\text { (phenyl, ortho, meta } \\
\text { and para) }\end{array}$ \\
\hline & $\begin{array}{c}1225- \\
950\end{array}$ & $\begin{array}{l}1054.08 \\
1054.08\end{array}$ & $\begin{array}{l}1027.06 \\
1098.44 \\
1170.04 \\
1098.44\end{array}$ & $\begin{array}{l}\text { Aromatic } \mathrm{C}-\mathrm{H} \text { in- } \\
\text { plane bend }\end{array}$ \\
\hline $\mathrm{C}-\mathrm{O}$ & $\begin{array}{l}1320- \\
1210\end{array}$ & - & 1259.77 & $\mathrm{C}-\mathrm{O}$ stretch \\
\hline $\mathrm{C}-\mathrm{H}$ & $\begin{array}{c}1470- \\
1430 / \\
1380- \\
1370\end{array}$ & 1463.48 & 1374.98 & $\begin{array}{l}\text { Methyl C-H } \\
\text { asym./sym. bend }\end{array}$ \\
\hline $\mathrm{C}=\mathrm{C}-\mathrm{C}$ & $\begin{array}{c}1615- \\
1450\end{array}$ & - & $\begin{array}{l}1460.98 \\
1582.03\end{array}$ & $\begin{array}{l}\text { Aromatic ring } \\
\text { stretch }\end{array}$ \\
\hline $\mathrm{C}=\mathrm{O}$ & $\begin{array}{c}1740- \\
1725\end{array}$ & 1735.65 & 1731.31 & Aldehyde \\
\hline $\mathrm{C}-\mathrm{H}$ & $\begin{array}{c}2960- \\
2850\end{array}$ & $\begin{array}{l}2849.65 \\
2919.04\end{array}$ & $\begin{array}{l}2851.52 \\
2919.97\end{array}$ & $\begin{array}{c}\text { Methyl C-H } \\
\text { asym./sym. stretch }\end{array}$ \\
\hline
\end{tabular}

\section{SEM Characterization}

We studied the surface morphology of sample from bitumen field and non-bituminous field using scanning electron microscopy (Figure 2). SLC contained more void spaces than SLSP, this is in line with a reported work [29] that uncontaminated soil contains more void spaces when compared with contaminated soil.
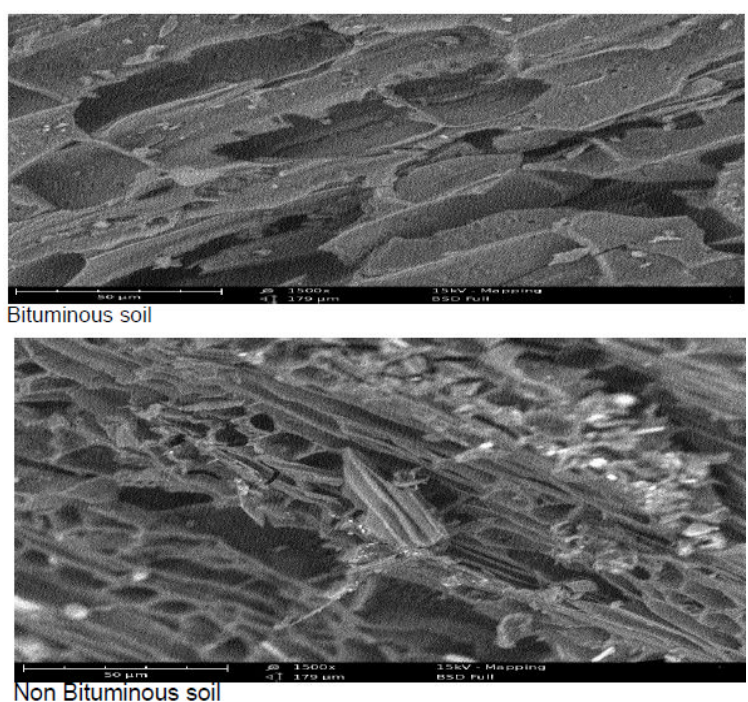

Figure 2. SEM micrograph of bituminous (SLE) and nonbituminous (SLC) soils
GC-MS Characterization for quantification of soil's PAHs

Figure 3 is chromatogram of SLE and SLC soil. Table 4 shows the PAHs concentrations in the samples. For individual PAH composition, most of the compounds analyzed were detected at all locations in soil samples. The levels of PAHs found in this study ranged from $0.61-26.11 \mathrm{ppb}$ in soil samples, where benzo [e]pyrene was the most dominant. PAH concentrations for soil samples were below the maximum allowable concentrations. An exception is a benzo[e]pyrene. Results showed that total concentration of PAHs (tPAHs) ranged from $4.31 \mathrm{ppb}$ in SLS to $82.40 \mathrm{ppb}$ in SLE.

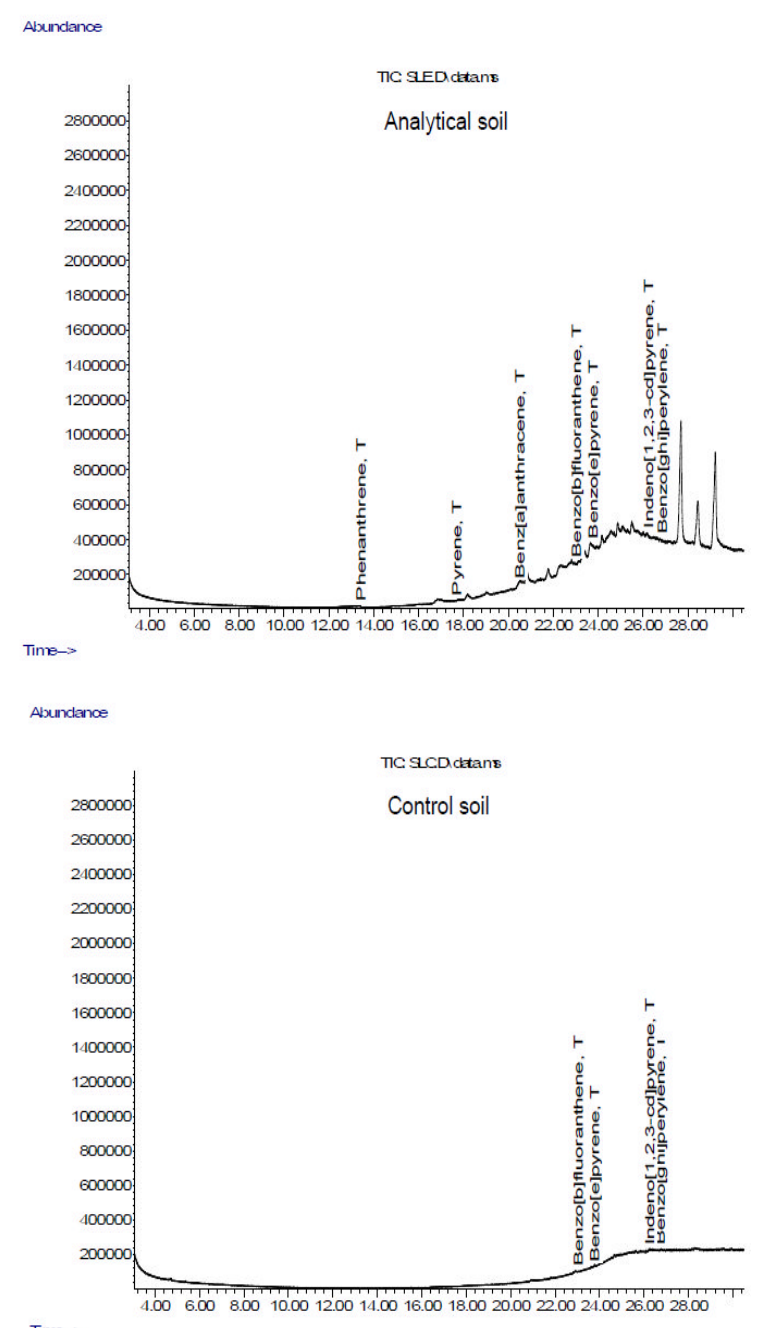

Figure 3. GC-MS chromatograms of bituminous (SLE) and nonbituminous (SLC) soils showing detected PAHs 
Table 4. PAHs Concentration in soil samples.

\begin{tabular}{|c|c|c|c|c|c|c|c|}
\hline \multirow[t]{2}{*}{ PAH } & \multicolumn{6}{|c|}{$\begin{array}{c}\text { PAH Concentration in Soil Sample } \\
(\mathrm{ppb})\end{array}$} & \multirow[t]{2}{*}{$\underset{(\mathbf{p p b})}{\sum \mathbf{P A H}}$} \\
\hline & SLSP & $S L N$ & $S L S$ & $S L E$ & $S L W$ & $S L C$ & \\
\hline Fluorene & BDL & BDL & BDL & BDL & BDL & BDL & BDL \\
\hline Phenanthrene & BDL & 6.34 & BDL & 4.16 & BDL & BDL & 10.50 \\
\hline Pyrene & 0.68 & 0.61 & BDL & 0.63 & 0.66 & BDL & 2.58 \\
\hline $\begin{array}{l}\text { Benz[a]anthra } \\
\text { cene }\end{array}$ & BDL & BDL & $\mathrm{BDL}$ & 3.36 & 1.44 & BDL & 4.80 \\
\hline $\begin{array}{l}\text { Benzo[b]fluor } \\
\text { anthene }\end{array}$ & 7.42 & 8.38 & 2.31 & 18.29 & 11.66 & 2.93 & 48.06 \\
\hline $\begin{array}{l}\text { Benzo[e]pyre } \\
\text { ne }\end{array}$ & 26.11 & 9.04 & 2.00 & 22.56 & 24.51 & 4.63 & 84.22 \\
\hline $\begin{array}{l}\text { Indeno[1,2,3- } \\
\text { cd]pyrene }\end{array}$ & 5.71 & 5.99 & BDL & 11.70 & 5.99 & 5.24 & 29.39 \\
\hline $\begin{array}{l}\text { Benzo[ghi]pe } \\
\text { rylene }\end{array}$ & 6.09 & 6.63 & BDL & 21.70 & 6.20 & 14.54 & 40.62 \\
\hline tPAHs & 46.01 & 36.99 & 4.31 & 82.40 & 50.46 & 27.34 & 220.17 \\
\hline
\end{tabular}

BDL is below the detection limit.

\section{Correlation analysis}

Figure 4 which shows the linear regression analyses for PAHs concentration and total organic carbon marked low positive correlation in soil samples $\left(R^{2}=0.4918\right)$. These shows site contaminated at different levels by cumulative parametric factors, meaning contaminations of soil with PAH are from various anthropogenic sources. Significant sources of PAHs in an environment are with ratios between pairs of concentrations of individual PAHs [10]. Results are correlated to mean concentration of PAHs. All the physicochemical parameters studied in soil samples except moisture content showed low positive correlation.
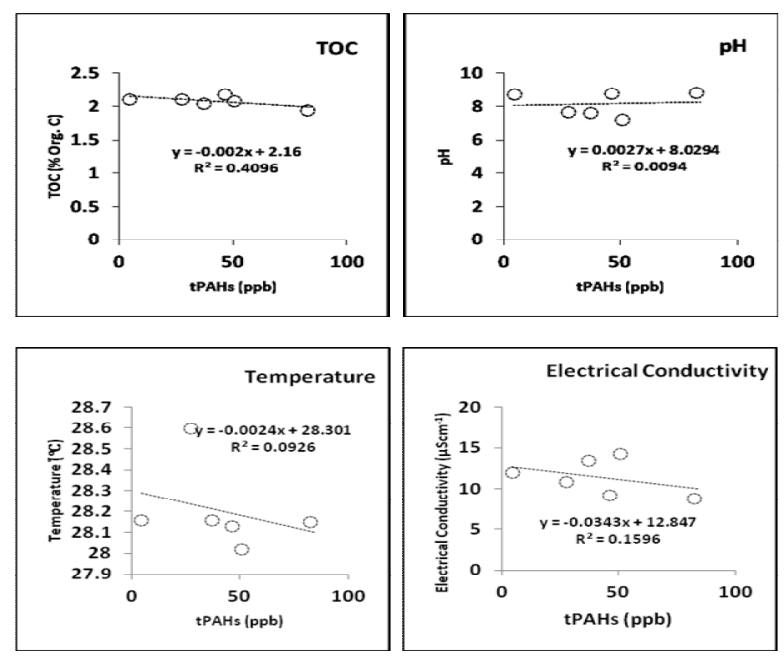

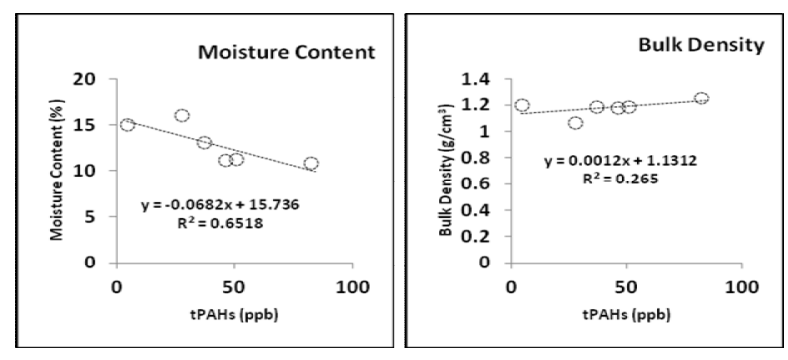

Figure 4. Regression Relationship between Parametric Factors and PAHs Concentration in Soil Sample

\section{GC-MS validation}

The repeatability of the analysis was performed by injecting the same standard three times in order to measure the precision of the results, and the reproducibility was also investigated by triple analysis. The results (Table 5) showed that the adopted method is repeatable and also reproducible as the RPD's values obtained were less than $10 \%$.

Table 5. LOD, LOQ and \% RDP as Estimated from the GC-MS Analysis.

\begin{tabular}{lccc}
\hline \multirow{2}{*}{ ANALYTE } & \multicolumn{3}{c}{ Quality Control Parameters } \\
\cline { 2 - 4 } & $\boldsymbol{L O D}(\boldsymbol{p p b})$ & $\boldsymbol{L O Q}(\boldsymbol{p p b})$ & $\boldsymbol{\%} \boldsymbol{R D P}$ \\
\hline Fluorene & 0.03 & 0.10 & 2.90 \\
Phenanthrene & 0.18 & 0.61 & 1.13 \\
Pyrene & 0.03 & 0.10 & 1.24 \\
Benz[a]anthracene & 0.10 & 0.32 & 5.78 \\
Benzo[b]fluoranthene & 0.12 & 0.40 & 4.40 \\
Benzo[e]pyrene & 0.12 & 0.40 & 4.49 \\
Indeno[1,2,3-cd]pyrene & 0.08 & 0.25 & 2.30 \\
Benzo[ghi]perylene & 0.06 & 0.21 & 1.13 \\
\hline
\end{tabular}

\section{Distribution of PAHS}

The prevalence of 4-6 rings PAHs in an environment shows that they are likely to be formed by pyrolysis (anthropogenic combustion). This agrees with a report [30], identifying coal as the major source of PAH. Out of PAHs studied, benzo[b]fluoranthene and benzo[e]pyrene were dominant in distribution in the soil samples having been detected across all the points. Other 4-6 rings PAHs that were detected in all the samples also confirmed that the major source of PAHs was anthropogenic. Their prevalence in the samples is because high molecular weight PAHs resists 
biodegradation and gathers in the environment [31]. Estimated PAH concentrations agree with values earlier reported [32,33]. Findings similarly point to carcinogenic PAHs previously reported [34] to exist in multiple times higher than standard permissive level. Phytoremediation has been reported [35] as the most effective technique for bioremediation of soil polluted by polycyclic aromatic hydrocarbons.

\section{Conclusions}

Findings from this study showed that all the soil samples were contaminated with PAHs. Their concentrations were below the maximum allowable limits except for few 4-rings members. The availability and concentrations of the studied analytes vary across the study area. The high molecular weight (HMW) PAHs are the prevalent with $\mathrm{B}(\mathrm{e}) \mathrm{P}$ concentrations in most of the samples. The FTIR studies confirmed the presence of aromatic compounds in the samples. The concentration of PAHs in soil samples are significant $(p>0.05)$ when compared with the maximum allowable values provided by Agency for Toxic Substances and Disease Registry in 2006. However, regular investigation on long-term effects of PAHs is needful.

\section{References}

1. M. A. Khan and A. M. Ghouri, J. Arts, Sci. Commerce, 2 (2011) 277.

2. WHO Guidelines for Drinking-water Quality, (2003).

3. B. Garban, H. Blanchoud, A. MotelayMassei, M. Chevreuil and D. Ollivon, Atmos. Environ., 36 (2002) 5395. doi:10.1016/S1352-2310(02)00414-4

4. K, Sexton, J. J. Sahmas, T. J. MacDonald, R. M. Z. Gowen, R. P. Miller, J. B. McCormick and S. P. Fisher-Hosh, Inter. J. Enviro. Res. Public Health, 8 (2011) 3365. doi:10.3390/ijerph8083365

5. P. N. Sibiya, (2012). A Ph.D thesis submitted to the Faculty of Science, University of the Witwatersrand Johannesburg, (2012) 227.

6. A. Ramesh, S. A. Walker, D. B. Hood, M. D. Guillen, K. Schneider and E. H. Weyand, $J$. Toxicol., 23 (2004) 301. doi:10.1080/10915810490517063
7. E. Gaga, Extract of Thesis, Department of Chemistry, Middle East Technical University, (2004) 254.

https://awc.metu.edu.tr/system/files/pdfs/thes is manual - 24.07.2015\%28new\%29.pdf

8. Y. Z. Gao and L. Z. Zhu, Chemosphere, 55 (2004) 1169.

doi:10.1016/j.chemosphere.2004.01.037

9. S. E. Agarry and K. M. Oghenejoboh, $J$. Microbial Biochem. Technol., 2 (2014) 5948. http://dx.doi.org/10.4172/1948-5948.S4-00

10. M. Bergknut, Sofjadern Offsett AB, Umea, Sweden, (2006) 6. https://www.diva-portal.org/smash/get/ diva2:140370/FULLTEXT01.pdf

11. E. O. Fagbote and E. O. Olanipekun, $1^{\text {st }}$ Annual International Interdisciplinary Conference, AIIC.24-26 April, Azores, Portugal, (2013).

http://academicjournals.org/ebook/journal14 25055330 AJB 25 February, 2015 Issue.pdf

12. C. Anyakora and H. Coker, Afri. J. Biotechnol., 5 (2006) 2024. doi: 10.5897/AJB06.484

13. E. O. Fagbote and E. O. Olanipekun, Eur. J. Sci. Res., 41 (2010) 373. http://www.bioline.org.br/pdf?st10055

14. D. R. Banjoo and P. K. Nelson, $J$. Chromatogr., 1066 (2005) 9. https://doi.org/10.1016/j.chroma.2005.01.033

15. Y. Huang, J. Wei, J. Song, M. Chen and Y. Luo, Chemosphere, 92 (2013) 1010 doi:10.1016/j.chemosphere.2013.03.035

16. R. E. E. Ana, M. K. C. Sridhar and G. O. Emerole, Afr. J. Pure Appl. Chem., 3 (2009) 31.

http://www.academicjournals.org/journal/AJ PAC/article-abstract/336BE631560

17. U. S. Environmental Protection Agency, OSWER Directive, 9285 (2007) 7.

18. R. B. Gomes, R. Nogueira, J. M. Oliveira, J. Peixoto and A. G. Brito, Environ Sci. Pollut Res., 16 (2009) 671. doi:10.1007/s11356-009-0118-4

19. D. Fabbri, A. G. Rombolà, C. Torri and K. A. Spokas, J. Anal. Appl. Pyrolysis, 103 (2013) 60. https://doi.org/10.1016/j.jaap.2012.10.003

20. E. O. Ifelola and A. C. Alaba, J. Emerg Trends Eng. Appl. Sci., 5 (2014) 99. 
http://jeteas.scholarlinkresearch.com/articles/ Investigation\%20of\%20Edaphic.pdf

21. P. R. Chaudhari, D. V. Ahire, V. D. Ahire, M. Chkravarty and S. Maity, Int. J. Sci. Res. Publications, 3 (2013) 1.

http://citeseerx.ist.psu.edu/viewdoc/downloa d?doi=10.1.1.299.7022\&rep=rep1\&type $=$ pdf

22. A. Naeem, H, Fayyaz-ul and Q. Ghulam, Int. J. Agri. Biol., 9 (2007) 509.

http://www.fspublishers.org/published_paper s/47893 ..pdf

23. M. C. Onojake and L. C. Osuji, Arch. Appl. Sci. Res., 4 (2012) 48.

http://www.scholarsresearchlibrary.com/artic les/assessment-of-the-physicochemicalproperties-of-hydrocarbon-contaminatedsoil.pdf

24. H. C. Samarakoon, P. A. Weerasinghe and W. A. P. Weerakkody, Trop. Agric. Res., 18 (2006) 13.

25. H. H. Oyem, I. M. Oyem and D. Ezeweali, Res. J. Environ. Sci., 8 (2014) 444. doi:10.3923/rjes.2014.444.450

26. USDA, Soil Quality Information Sheet, U.S. Department of Agriculture, (1998) 2. https://www.nrcs.usda.gov/Internet/FSE_DO CUMENTS/nrcs142p2_052502.pdf

27. L. D. Richard and E. W. Gordon (1983), USDA Forest Service, Colorado (1983). https://www.fs.fed.us/psw/publications/docu $\underline{\text { ments/psw_gtr198/psw_gtr198_b.pdf }}$
28. J. Coates, Encyclopedia of Anal. Chem. John Wiley \& Sons, Chichester, (2000) 10815. doi: 10.1002/9780470027318.a5606

29. S. Roshni and S. P. Jeyapriya, International Conference on Geotechniques for Infrastructure Projects, 27th \& 28th February 2017, Thiruvananthapuram, (2017).

30. J. Y. Wenlai Xu and H. Cheng, Atmosphere, 9 (2018) 63.

http://dx.doi.org/10.3390/atmos9020063\%20

31. B. Ryan, M.Sc. Thesis submitted to the School of Environmental Sciences University of East Anglia, University Plain Norwich, (2013).

32. A. Olajire and W. Brack, Int. J. Environ. Sci. Tech., 2 (2005) 343. doi:10.1007/BF03325895

33. O. O. Emoyan, E. E. Akporhonor, P. O. Agbaire and S. O. Akporido, Int. Rese. J. Public and Environ. Health, 2 (2015) 70. https://journalissues.org/wpcontent/uploads/2015/06/Emoyan-et-al..pdf

34. H. Jiao, Q. Wang, N. Zhao, B. Jin, X. Zhuang and Z. Bai, Int. J. Environ. Res. Public Health, 14 (2017) 1198.

35. Z. Košnár and P. Tlustoš, Plant Soil Environ., 64(2018) 88. doi: 10.17221/39/2018-PSE 